\title{
Biodiversity and perceptions of risk: Reactions to the use of a single donor for stem-cell-derived red blood cell transfusions
}

\author{
Dr Emma King* \\ NMAHP-RU, University of Stirling
}

\begin{abstract}
Blood transfusion is a well-accepted medical technology that currently relies on a supply of red blood cells from many thousands of altruistic donors. Cultured red blood cells using stem cell technology could offer a replacement technology, providing a limitless supply of red blood cells from a single source. This project used interviews and focus groups to explore the views of a wide range of publics towards cultured red blood cells. This paper explores how participants referred to a lack of biodiversity in cultured red blood cells in three ways. The first was as a comparison to GM crops, with concern over a monopoly on blood supplies. The second was a perceived increased risk associated with a single source of blood. Thirdly participants saw the lack of biodiversity as a threat to the altruistic nature of blood donation from multiple donors.
\end{abstract}

\section{Introduction}

This paper is about a research project which looked at the views of various publics towards the use of stem-cell-derived red blood cells for transfusion. During the course of the research it was found that many participants compared this new technology with that of genetically modified (GM) crops. In this paper I discuss how, in interviews and focus groups, GM crops were used to describe a perceived lack of biodiversity. I introduce the transition to cultured red blood cells as a continuation of historical aspects of blood donation, to show the transition from donor gift to potential laboratory project. I will also look at the attitudes towards GM crops in the UK, to discuss how a perceived lack of biodiversity and the 'scientification' of nature are regarded as inherently more risky.

* DOI $10.7590 / 221354015 \mathrm{X}_{14488767262796}$

The author acknowledges the assistance of the many people who contributed to this research, particularly Professor Catherine Lyall. I thank Dr Joanne Mountford and the other members of the Novosang consortium for information and support throughout the project. The financial support of the Scottish Funding Council is acknowledged (SFC Grant Number 227208694). 


\section{The historical context of donor blood transfusion}

Although bloodletting was first recorded in $430 \mathrm{BC}$ and remained a common practice until the nineteenth century, ${ }^{1}$ blood transfusion is a relatively recent clinical practice. In 1628 Harvey's $^{2}$ book provided the knowledge needed for early animal transfusion experiments by Lower in 1665 and Cox in 1666-67.3 The recognition of the need to transfuse humans only with human blood 1818 was made by James Blundell, with blood types identified by Karl Landsteiner in $1901 .{ }^{4}$ Routine blood typing was not practised until the 1920 , with the rhesus positive and negative blood types identified in $1941 .^{5}$ Percy Oliver's list of blood donors was started in $1921^{6}$ but it was not until 1937 that Bernard Fantus set up the blood bank as we now know it, with blood refrigerated for up to ten days. Today blood is one of medicines' 'most vital commodities $^{77}$ and the UK alone transfuses 2.2 million units of blood each year. Donation and transfusion is overseen by the NHS, with four transplant services covering England and North Wales, South Wales, Northern Ireland, and Scotland. The Scottish National Blood Transfusion Service (SNBTS) is the main focus of the research reported in this paper.

\section{The need for a new method of transfusion}

The UK has an established and effective blood donation system but there are challenges which highlight the need for alternative methods of blood transfusion. Preventing contamination of donated blood with transfusion transmitted infections (TTIs) requires large amounts of blood testing, bringing with it associated rises in cost. ${ }^{8}$ Acquiring adequate donors is another major hurdle, with donor numbers falling and the UK transfusion services heading towards a recruitment crisis. Currently only $4 \%$ of the UK population are re-

P. Giangrande, 'The history of blood transfusion', British Journal of Haematology 110:4 (200), 758-767.

2 W. Harvey, Exercitatio Anatomica de Motu Cordis et Sanguinis in Animalibus (1628).

H. Brown, 'Jean Denis and Transfusion of Blood, Paris, 1667-1668', Isis 39:1/2 (1948), 15-29.

K. Landsteiner, Ueber Agglutinationserscheinungen normalen menschlichen Blutes (1901).

K. Landsteiner \& A.S. Wiener, 'Studies on an agglutinogen (rh) in human blood reacting with anti-rhesus sera and with human isoantibodies', The Journal of Experimental Medicine, 74:4

(1941), 309-320.

6 See footnote 1.

7 D. Starr, Blood: an Epic History of Medicine and Commerce (Little, Brown and Company, 1999), $\mathrm{x}$.

8 E. Ferguson, C. Prowse, E. Townsend, A. Spence, J.A. van Hilten, \& K. Lowe, 'Acceptability of blood and blood substitutes', Journal of Internal Medicine 263:3 (2008), 244-255. 
gistered blood donors, ${ }^{9}$ and the Scottish National Blood Transfusion Service expressed a need to raise the donor levels from 175,000 in 2008 to 210,000 in $2010 . .^{10}$ Many innovations have been proposed to overcome the dual challenges of donor recruitment and possible infection risk. Haemoglobin-based oxygen carriers (HBOCs), , derived from human or animal blood and Perfluorocarbons (PFCs), ${ }^{12}$ which are synthetic oxygen carriers, were heralded as an alternative to red blood cell transfusion. Unfortunately neither product performed well in clinical trials and are not licensed for use in the UK or USA. ${ }^{13}, 14$

This paper concerns the Novosang product, which is another proposed technology to overcome both the requirement for donors and the infection risk. Rather than using chemical substitutes for blood, the project goal is to culture red blood cells in the laboratory, providing a limitless and infection free source of blood for transfusion. To date the project has received over $£ 12$ million in funding from organisations including the Wellcome Trust, the Scottish Funding Council, Scottish Enterprise, the Scottish National Blood Transfusion Service and NHS Blood and Transplant. ${ }^{15}$ By the time the project finishes it is hoped that it will generate small quantities of blood suitable for initial animal and human safety tests.

The reaction of the wider public to this novel method of producing red blood cells was unknown. Blood donations in the UK come from altruistic donors, which has impacted on the interesting 'gift relationship' view of blood transfusions, as was portrayed in Titmuss ${ }^{16}$ book of the same name. Studies have shown that donated blood is still preferable to other forms of blood replacement. Ferguson et al. ${ }^{17}$ found that the public viewed blood substitutes as a 'substandard replacement' for actual blood, an unnatural and synthetic alternative. A study carried out by Fleming et al. ${ }^{18}$ found that those studied had a preference for donor blood, being regarded as the most effective, most ethically acceptable

9 National Health Service, 'Introduction to blood donation', www.nhs.uk/conditions/Blooddonation/Pages/Introduction.aspx (last accessed 18/03/2015).

10 National Health Service, Report: Meeting the transfusion needs of patients in Scotland. Scottish National Blood Transfusion Service (2008).

11 T.A. Silverman \& R.B. Weiskopf, 'Haemoglobin-based Oxygen Carriers: Current Status and Future Directions', Anesthesiology 111:5 (2009), 946-963.

12 C.S. Cohn \& M.M. Cushing, 'Oxygen therapeutics: Perfluorocarbons and blood substitute safety', Critical Care Clinics 25:2 (2009).

13 T. Henkel-Honke \& M. Oleck, 'Artificial oxygen carriers: a current review', Aana J. 75:3 (2007), 205-211.

14 S.J. Grethlein \& A. Rajan, 'Blood Substitutes', Medscape Reference (2012).

15 See more at www.novosang.co.uk.

16 R.M. Titmuss, The Gift Relationship: From Human Blood to Social Policy (LSE Books, 1997).

17 See footnote 8 .

18 P. Fleming, E. Ferguson, E. Townsend \& K.C. Lowe, 'Perceptions in transfusion medicine: a pilot field study on risk and ethics for blood and blood substitutes', Artificial Cells, Blood Substitutes, And Immobilization Biotechnology 35:2 (2007), 149-156. 
and least 'risky'. This was followed by chemical-based substitutes, bacteriagrown substitutes and finally bovine-derived substitutes, which were seen as being the most risky, least ethically acceptable and least effective. Notably, perceptions of risk correlated with both ethicality and effectiveness for all of the options. The Fleming study shows that human donor blood was still seen as the preferred option by those who were interviewed. Other research on blood and blood substitutes has identified a greater acceptability of blood substitutes amongst medical professionals, when compared to journalists or blood donors. ${ }^{19}$ There was also a marked difference between the risk levels perceived by these groups concerning the infection rates through donation. However, none of these papers looked at cultured red blood cells using stem cell technology, and Ferguson et al. argued that a more effective 'marketing' of alternative blood products may change the views that their respondents had expressed. Previous developments in the blood products industry, such as the use of recombinant DNA technology to provide Factor VIII, show that it is possible for an alternative technology to become assimilated into mainstream practice.

This project set out to discover the reactions of various publics in Scotland towards cultured red blood cells. In this paper I report specifically on the theme of biodiversity as it was used by our participants in interviews and focus groups, and particularly as it was used in comparison to GM crops. Given the focus of this paper it is necessary to understand how such crops are viewed in the context of the UK, where this research was conducted.

\section{GM crops in the UK}

GM crops in the UK (and in the rest of Europe) have not been publicly accepted in the way that such crops have been in areas such as North America and China. ${ }^{20}$ Since 2001 only one GM crop has been approved for cultivation in Europe. ${ }^{21}$ Images of protesters in biohazard suits destroying fields of GM crop tests were widely portrayed in the UK media during the late 1990 s. The website www.genewatch.co.uk states that currently no commercial GM crops are grown in the UK although testing of such crops does continue. GM products enter the UK from abroad in food, animal feed, and biofuels. At the

19 K.C. Lowe, K. Farrell, E.M. Ferguson \& V. James, 'Current perceived risks of transfusion in the UK and relevance to the future acceptance of blood substitutes', Artificial Cells, Blood Substitutes, And Immobilization Biotechnology 29:3 (2001), 179-189.

20 D. Burke, 'GM food and crops: what went wrong in the UK? Many of the public's concerns have little to do with science', EMBO Reports 5:5 (2004), 432-436.

${ }^{21}$ Y. Devos, O. Sanvido, J. Tait \& A. Raybould, 'Towards a more open debate about values in decision-making on agricultural biotechnology', Transgenic Res. 23:6 (2014), 933-943. 
time of writing this paper (August 2015) debates have once again resurfaced in the media after Scotland declared a ban on the growing of GM crops.

Fears about GM crops in the UK have stemmed from a perception that transgenes used in GM crops could transfer into other wild plants or non-GM crop species. ${ }^{22}$ There has also been a backlash on moral principles towards large commercial companies having control over crop production. Terminator technology, which prevents farmers from storing seed for planting the following year, means that growers must return to the GM company and rebuy seed each year. Some consider this to be locking farmers into a continuing relationship with the commercial company, whilst others see this as the only way to prevent crops spreading in the wild and for companies to guarantee a return on their investment. Some argue that basing a risk assessment of GM crops on public attitudes has distanced the argument from scientific facts, pointing out that many of these risk factors have been founded on human emotions and not on scientific data. ${ }^{23}$

\section{Methods}

As part of our research into this new method of producing blood, focus groups and interviews were carried out with a variety of publics. The research methods used for this project will be described in more detail elsewhere.

Four key groups were targeted:

- Patients who undergo regular blood transfusions, for example for sickle cell disease or thalassaemia.

- Representatives of religious or moral groups who could contribute to the discussion on cultured red blood cells from an ethical or religious standpoint.

- Clinical groups, such as doctors and nurses, who use blood transfusions in the course of their work.

- Community groups chosen to represent a spread of publics, who may not have a background in science or medicine. These included sports clubs, arts groups, etc.

Interviews were conducted with those who it were felt were 'experts' in their field - which included doctors, ethicists, members of religious organisations,

22 A.F. Raybould \& A.J. Gray, 'Will hybrids of genetically modified crops invade natural communities?', Trends in Ecology \& Evolution 9:3 (1994), 85-89.

23 J. Tait, 'Upstream engagement and the governance of science. The shadow of the genetically modified crops experience in Europe', EMBO Reports 10:S1 (2009). 
and patients. Focus groups were used to bring together those who might not have previously considered the issues involved in cultured red blood cells, and included community and sports groups, a college group, and residents in a residential care home for the elderly. The majority of data collection took place in Scotland, apart from a focus group with one patient group which took place in London, and one expert interview in northern England. In total there were 27 data collection sessions, including interviews, full focus groups (approx. two hours) and mini focus groups (which ran from a few minutes to one hour and were often unrecorded). The interviews and focus groups which had been voice recorded were transcribed verbatim and then the transcripts and notes from unrecorded sessions were coded using NVivo software. A grounded theory methodology ${ }^{24}$ was used, to draw information from the data rather than starting with preconceived theories. In total 22 nodes were used, of which one of these described the views of the interviewees towards the 'biodiversity' of the cultured blood product.

\section{Results}

The theme of biodiversity was discussed by our respondents in a number of ways. These included feelings of 'everything being the same', and of cultured blood production being like 'GM crops'. These conversations around biodiversity are divided into three interlocking themes of commercialisation, risk associated with a lack of biodiversity, and social considerations.

\section{Theme 1: Commercialisation}

The first theme saw participants compare cultured red blood cells to the perceived commercialisation of GM crops. Participants reflected on the way that a 'free' product was being turned into a profit making facility - both in the commercialisation of crops which would grow naturally and in the commercialisation of blood which is currently obtained from altruistic donors. This of course glosses over many of the current production costs necessary in both farming and blood transfusion. With increased commercialisation came an appreciation of the rising power wielded by those in control of the product.

"And my sinister side would say, is there any way that a large corporation could say "and you now need to come back to us" and there would be some kind of power base. Like the genetically modified crop companies in the US who have made it so that any farmer now wanting to farm for the major supermarket chains will then

24 A.L. Strauss \& J. Corbin, 'Grounded Theory Methodology', in: N.K. Denzin \& Y.S. Lincoln (eds.), Handbook of Qualitative Research (Sage, 1994). 
harvest the grain and will need to go back to the GM company because it only has a rate of regeneration for one year only. And you are then going cap in hand again to buy more seed. And they have deliberately done that in their economic engine of "and you will need us".' (Interview)

Participants raised concerns that the use of blood would be restricted to those who could afford to pay for it, and that the supply of blood might be tied to a particular commercial company who had control over the use of blood by health-care systems. There was also a feeling of unease that commercial companies were profit driven and more likely to cut corners in the pursuit of profits over consumer safety. In contrast there was high trust in public bodies such as the blood transfusion services and the NHS.

However this discussion on commercialisation was tempered in part by a realisation that commercial companies are necessary in the development of healthcare technologies, and that we already rely heavily on such companies to innovate new pharmaceutical products and devices.

'Pretty much all the drugs that have been developed have been developed by industry for commercial gain but it benefited everyone hugely and probably half of these drugs wouldn't be here if it wasn't for the commercial drive to do it. It's all very well saying it's for public good and it should be for everyone but that's not how things get developed, or very expensive things get developed. It seems that the blood thing is coming from this position that we're in now where there's this ethos of giving and it's available to everyone and it's not for profit. There's a sort of a tension.' (Focus group)

'Can I suggest, we're talking from a slightly naïve point. We in the UK have this perception of everything being free on the NHS, albeit we're paying for it through other methods, this is not something that is going to be exclusively done in the UK, this is going to be taken up in America or wherever else, either now or at some point in the future. So whether it's developed in the UK and then licensed out or whether America says we can do this as well. Who's going to pay for that? Is it going to be private companies who see the long-term game plan that would make billions out of it, and without that private money going in, is it ever actually to get to the point of making it to production? I've no idea how much the Wellcome Trust has, and if they're the only body who are involved in this, but sooner or later surely they're going to say, wait a minute we've spent it all, and this is going to run for 20 years until it comes to production.' (Focus group)

There was a lack of awareness amongst many of the participants about the true cost of many healthcare practices in the UK, including blood donation, which the participant is referring to here, and which will be discussed further below. 
KING

Theme 2: Lack of biodiversity as increased risk

People also compared cultured blood to GM crops as a view that a lack of biodiversity was somehow riskier. In some unrecorded mini-focus groups the participants referred to the problems of having all the eggs in one basket (what would happen if something went wrong), or of a general (but unspecified) unease about 'everything being the same'.

'I meant in terms of the practicalities, would it not be better to have a cocktail of individuals come together for the red blood cells, for your stock? But I don't know whether that is a technical issue. Just thinking from a general biological perspective, having your feedstock based on a single individual can run into problems, and often unexpected problems. Although I appreciate that with red blood cells you've not got the genetic issue. I don't know enough about the technicalities but just from a general biological perspective I don't know how wise it would be to base it all on a single individual, but I'm sure your guys know what they're doing.' (Interview)

Despite the fact that there might not be a biological basis for a lack of biodiversity to result in increased risk, it was recognised as a legitimate risk factor that many people might identify. This interviewee believed that this stemmed from the fear of the unknown about cultured blood products, although in this case it was compared to irradiated foods rather than GM crops.

'That sense of perception that "I don't know how all this stuff works, but natural to have reactions like thinking this may be passed on". Similar to the reactions to irradiated food etc. In terms of scientific rationale it is completely wrong, but it terms of how people frame issues then that is the way that they think.' (Interview)

Again this was balanced by the view that a lot of the reactions we have to GM crops have been picked up from media stories, and do not necessarily reflect reality.

'You'd think some of the reception in the greater world out there would depend on how the media present this, in focus groups like this we can talk calmly and rationally about it but how would the media present it to the greater population? We've seen the GM foods, Frankenfoods and all this kind of thing, how would that be presented? That would be a concern as to how the scientific world presented it via the media, what the media actually took.' (Focus group)

Theme 3: Cultured blood in a social context

The final theme was that of biodiversity affecting how we view cultured blood in a social context. Currently blood in the UK is given by many thousands of anonymous donors and has a strong sense of 'gift giving'. However as participants raised, this may change if all the blood being produced is coming from one or a small number of stem cell lines. 
'But if things, if everything can be bought or sold, if the concept of gift is no longer something that is valued in society, people in America sell their blood, apparently all along the border with Mexico there's a whole lot of blood clinics because they're getting the blood from the poor Mexicans. If this concept of solidarity, a gift is no longer valued or even made possible then I think society as a whole will be weakened.' (Interview)

In this quote the interviewee appears to be relating a change in the social context of blood donation to the increased commercialisation and profit making around blood. Whereas in the quote below the participants are reflecting on the perceived lack of biodiversity, with all the blood coming from a single source rather than the many altruistic donors.

'F1: I guess there's also the point that there might be six or ten nationwide sources of this blood, six or ten people walking around in the UK whose blood is now in the veins of a million people, and that's not how it is at the moment [?] people, whether that would bother people.

F2: I suppose it's removing diversity, isn't it ...

F1: People would have a problem with that, the way that people have problems with perceiving organs more than they do giving blood for some reason carrying part of that person around with them, does it make a difference if everyone is carrying a part of the same person?' (Focus group)

Although red blood cells only last around 120 days in the body there is still a perception that one is receiving part of another person, although, as is highlighted in the quote, perhaps less than through an organ transplant.

\section{Discussion}

Focus group and interview participants discussed biodiversity in the context of cultured blood in three ways. The first was a comparison of cultured blood to GM crops, the second was a perceived increased risk in cultured blood, and the third theme was a supposed social difference between cultured and donated blood.

In the first theme participants compared cultured blood to GM crops as a commercialisation of something which is regarded as intrinsically 'free'. It was argued that this commercialisation might lead to restrictions on access to blood. A socioeconomic concern about GM crops has been the terminator technology put in place by some GM crop companies, which renders GM seeds sterile. If farmers wish to continue with the GM crops they must return to the company each year to buy seeds, which some see as creating a monopoly by the GM seed 
companies. ${ }^{25}$ Similarly participants highlighted the potential risk of a cultured blood company putting a high price on blood which would make it unaffordable for the NHS or for individuals. In comparing cultured blood to GM crops our participants were reacting to what they saw as the restriction of something natural and 'free', a monopoly on something which is currently given as an altruistic gift. ${ }^{26}$

Such discussions speak to a wider question of commercialisation vs. open source science. ${ }^{27}$ On one hand technologies such as GM crops, or cultured blood, are seen to commercialise something which is regarded as naturally available. On the other hand a lack of monetary incentive could dissuade commercial involvement in future research. ${ }^{28}$ In the UK the true cost of blood production remains relatively hidden within the 'black-box' of the NHS. But the large amounts of processing and testing carried out means that blood is essentially already a commercialised product, with a biovalue that is becoming increasingly recognised. ${ }^{29,30}$ Indeed some participants attempted to raise the issue that we rely on commercialisation all the time for pharmaceutical developments, but that we simply are not aware of this because everything is done through the umbrella of the NHS. They were also aware that the NHS is unlikely to produce all the blood necessary for the entire world, meaning that other countries may be able to set prices for cultured blood which are outside the control of the UK developers.

Cultured red blood cells were perceived by participants to be more risky due to their perceived lack of biodiversity, compared to the current donation system which acquires blood from many individual donors. Increased risk was seen due to the possibility that, with a single stem cell line, if problems were found in this blood then thousands of people would be affected. Participants felt that to produce only one blood source was akin to 'putting all the eggs in one basket', with no knowledge of what might happen in years to come or whether that stem cell line would turn out to have some vital flaw. Conversely one of the aims of cultured red blood cells is to reduce the risk disease transmission due to the current method of obtaining blood from many different donors. The transfer of hepatitis from donor to recipient was an ongoing problem for many years,

S. Rastogi Verma, 'Genetically Modified Plants: Public and Scientific Perceptions', ISRN Biotechnology (2013), 11 .

See footnote 18 .

T. Caulfield, S.H. Harmon \& Y. Joly, 'Open science versus commercialization: a modern research conflict?', Genome Med. 4:2 (2012), 17.

A. Courtney, P. de Sousa, C. George, G. Laurie \& J. Tait, 'Balancing open source stem cell science with commercialization', Nat Biotechnol. 29:2 (2011), 115-116.

H. Busby, J. Kent \& A.-M. Farrell, 'Revaluing donor and recipient bodies in the globalised blood economy: Transitions in public policy on blood safety in the United Kingdom', Health 18:1 (2014), 79-94.

C. Waldby \& R. Mitchell, Tissue Economies: Blood, Organs and Cell Lines in Late Capitalism (Duke University Press, 2006). 
however more widely publicised was the HIV contamination of plasma products, which was first recognised in the early 1980 s and affected many haemophiliacs. $^{31,} 3^{2}$ The authorities were slow to inform patients or withdraw infected batches, which Starr ${ }^{33}$ attributes to the reverence given to blood and its symbolic nature as a social gift, rather than a pharmaceutical product. Previous work, however, has shown that despite infection risks donated human blood is still preferred over any other source, ${ }^{34,} 35$ including bovine derived, and synthetic blood. This work, however, did not take into account the prospect of stem cell derived blood, which is still human blood, just produced in a laboratory.

Finally the participants discussed biodiversity as it affects the social element of blood donation. This theme was heavily intertwined with the perception of risk from a lack of biodiversity, but focused more on the social connections between blood donors and recipients. Red blood cells have no nucleus or nuclear DNA, yet one group specifically said that this did not change their minds because there could be 'something else' (which was undefined) which meant that the blood given by each different individual was unique to them. There was inherent unease about all the blood in the UK potentially coming from a single individual (even if that 'individual' is a stem cell line). For so many years the public in the UK have been used to blood coming from multiple donors, an act of altruism which has led to the many comparisons between blood donation and gift giving. There is still a view that some of the individual is transferred in some way through donation, be that a donation of blood or organs. ${ }^{36}$ With blood donation in the UK currently using altruistic donors there is an element of 'not knowing' where this blood comes from and who the original donor is. In contrast this cultured blood is a known entity, as every recipient will be getting red blood cells grown from a single (or a small number) of donor lines.

Blood appears to fit a special criteria, especially in the UK, given the attachment to the transfusion services and the gift relationship around blood. Many participants seemed unable to articulate exactly what is was about the lack of diversity in red blood cells that they disliked, almost in the manner of the 'yuck' factor. ${ }^{37}$ Participants also did not compare the blood to any other technologies, although this may have been for two reasons, one that they were not prompted

31 D. Starr, Blood: an Epic History of Medicine and Commerce (Little, Brown and Company, 1999), 262.

32 The Penrose Inquiry, The Penrose Inquiry: Preliminary Report (APS Group, 2010).

33 D. Starr, Blood: an Epic History of Medicine and Commerce (Little, Brown and Company, 1999), 130.

34 See footnote 18

35 See footnote 8 .

36 M. Lock, Twice Dead: Organ Transplants and the Reinvention of Death (University of California Press, 2002).

37 C.W. Schmidt, 'The yuck factor: when disgust meets discovery', Environ Health Perspect. 116:12 (2008), A $524-527$. 
down this route by the focus group/interview facilitator, and the other that we tend to compare new technologies with those we are used to or estimate risks based on those technologies which are more prevalent in the media. ${ }^{38}$ It is perhaps unsurprising that participants were not so well acquainted with other comparable technologies such as synthesised insulin or Factor VIII, but were more aware of higher profile technologies such as blood transfusion and GM crops. This would be a limitation of this study, as it is with all qualitative studies, that the influence of the questions asked and the particular setting of the group or interview can have such a strong influence on the outcomes. However, given that so many of the groups and interviews brought up the issue of GM crops without prompting gives some weight to the idea that this topic was foremost in participants' minds as a comparator technology.

Younger respondents did not appear to have such an attachment to the donation system as the older ones did, and therefore saw the cultured red blood cells as clean, more sci-fi and scientific. This seems to be linked to the general lack of contact with the blood transfusion services compared to older participants, many of whom had either received a transfusion or had been donors for many years. Indeed this compares more with the reaction of the scientists themselves, who see less risk in the standardisation of blood, as it will come from a single 'known' source rather than many 'unknown' donors. With risk perception based on the perceived 'trustworthiness' of companies ${ }^{39}$ it will be interesting to see how this affects the risk perception of cultured blood, given that both this and donated blood are associated with the SNBTS. One possibility is that perceptions about the role of the blood transfusion services change as cultured blood becomes more prominent. Division in attitudes between younger and older audiences is therefore an area which would benefit from further study. Carrying out this research in the UK has highlighted issues that may have not been expressed elsewhere, because the expectation in the UK is that everybody, regardless of their income, receives all the health care that they require for no cost. This has the additional result of making healthcare in the UK a black-box, with many of us having no idea of the true cost of pharmaceuticals or medical procedures. It is worth noting that if this data had been collected in the US, for example, then reactions to this issue of commercialisation may have been very different. This comparison with other countries is an important area for further study.

38 B. Fischhoff, A. Bostrom \& M.J. Quadrel, 'Risk perception and communication', Annu. Rev. Public Health 14 (1993), 183-203.

39 M. Siegrist, 'The influence of trust and perceptions of risks and benefits on the acceptance of gene technology', Risk Analysis 20:2 (2000), 195-204. 


\section{Conclusion}

In conclusion, the data show that participants compared cultured red blood cells with GM crops and saw a lack of biodiversity as inherently risky and a threat to the established social ties of donated blood. The commercialisation of a natural product led to concerns about the monopoly of blood, leaving it only available to those with the ability to afford it. Cultured blood was seen as more risky if all the blood came from one stem cell line, despite ongoing problems with infection risks linked to the large number of altruistic donors currently involved in the supply of red blood cells for transfusion. Finally the altruistic and gift-like nature of blood was seen as being replaced by the homogenous donor blood, and in doing so some of the social interaction of blood transfusion was being removed. Although only a small number of our participants were young adults (18-25 years) they appeared to have a weaker attachment to the transfusion services and viewed the cultured blood as cleaner and more scientific. This was therefore a suggestion for further work, alongside a comparison of the attitudes to cultured blood in countries which do not operate under a system of national health provision. 